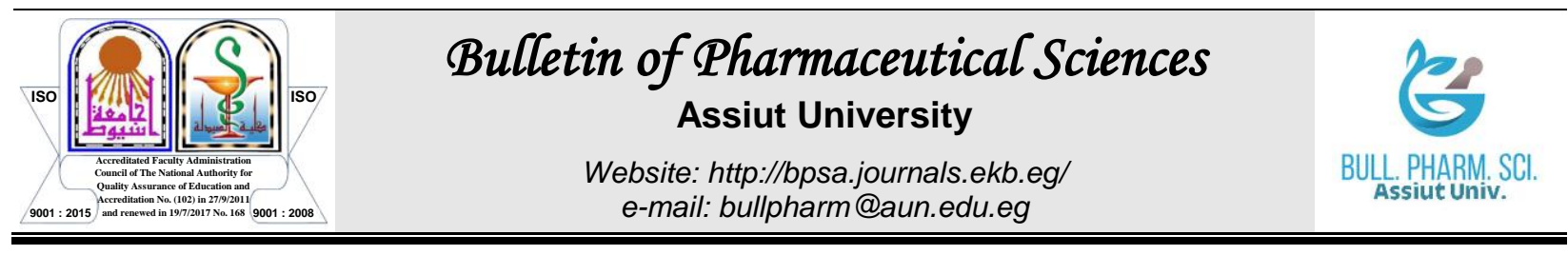

\title{
EFFECT OF DIFFERENT DOSES OF METFORMIN TABLETS ON METABOLIC SYNDROME COMPONENETS IN WOMEN WITH TYPE 2 DIABETES MELLITUS IN GORGAN (SOUTH EAST OF CASPIAN SEA)
}

\author{
Mona Mirzaali ${ }^{1}$, Jale Yuzugulen ${ }^{1}$, Taghi Amiriani ${ }^{2}$, Majid Marjani ${ }^{1 *}$ and Abdoljalal Marjani ${ }^{3 *}$ \\ ${ }^{1}$ Faculty of Pharmacy, Eastern Mediterranean University, 99628, Famagusta, North Cyprus \\ via Mersin 10, Turkey. \\ ${ }^{2}$ Golestan Research Center of Gastroenterology and Hepatology, Golestan University of \\ Medical Sciences, Gorgan, Iran. \\ ${ }^{3}$ Metabolic Disorders Research Center, Department of Biochemistry and Biophysics, Faculty \\ of Medicine, Golestan_University of Medical Sciences, Gorgan, Golestan province, Iran.
}

Studies on oral anti-hyperglycemic drugs have been shown in some studies to help and treat type 2 diabetic patients. The present study was designed to evaluate and compare the effect of different doses of metformin tablets on metabolic syndrome components in type 2 diabetic women in Gorgan, South East of Caspian Sea.Forty type 2 diabetic patients received $500 \mathrm{mg} /$ day and $1000 \mathrm{mg} /$ day metformin tablets for 12 months and forty healthy women were included in this study. The ATP III criteria were used to determine metabolic syndrome components, and lipid profiles, HbAlc and insulin were measured. Significant differences were found between blood sugar, triglycerides, high-density lipoprotein (HDL)-cholesterol, hemoglobin Alc (HbAlc) and insulin of the patients received $500 \mathrm{mg} /$ day and $1000 \mathrm{mg} /$ day metformin monotherapy. The blood sugar, triglycerides and insulin were significantly lower in patients received 500 and $1000 \mathrm{mg}$ /day metformin than control groups. In both groups, HDLcholesterol was higher than control groups, but HbAlc was significantly higher and lower in patients received 500 and $1000 \mathrm{mg} /$ day metformin than control groups, respectively. In both study groups, positive significant correlation was found between blood glucose and HbAlc and, blood glucose and triglyceride levels. Our study showed the efficacy of the $1000 \mathrm{mg} /$ day metformin monotherapy on better control of blood sugar, HbAlc, triglyceride and HDLcholesterol levels, but Metformin had no effect on waist circumference and blood pressure. Treatment with this dose of metformin may be more beneficial for type 2 diabetic patients than those other doses.

\section{INTRODUCTION}

The prevalence of diabetes mellitus (DM) was estimated to be $4.4 \%$ worldwide in $2030^{1}$. Diabetes mellitus (DM) is one of the most important causes of mortality worldwide. The diabetes mellitus can cause some diseases such as blindness, kidney failure, heart attacks, and stroke and lower-limb amputation ${ }^{2}$. The prevalence of diabetic people has increased and its prevalence is still rising ${ }^{2-3}$. In diabetic people, especially type 2 diabetic people, lacking of glycemic control can affect blood vessels and nerves, progression of neuropathies, micro-and macro-vascular complications and premature death ${ }^{2}$.Metabolic syndrome (MetS), is a cluster of some factors such as abdominal obesity, elevated blood pressure, dyslipidemia and dysglycemia ${ }^{4}$. These are an important risk factor for DM. Some studies have shown that MetS is predictor of DM incident ${ }^{5-7}$. However, the clinical effect of MetS is not exactly cleared.

Received in 22/2/2021 \& Accepted in 14//4/2021

*Corresponding author: Abdoljalal Marjani, E-mail: abdoljalal@yahoo.com 
According to the American Diabetes Association and the European Association for the Study of Diabetes suggestion, there is an association between MetS and DM due to impaired fasting glucose or impaired glucose tolerance ${ }^{8}$. The Diabetes Prevention Program (DPP) revealed that the risk of developing diabetes was decreased $58 \%$ by intensive lifestyle and $31 \%$ by metformin interventions in groups with IGT compared with control groups. The DPP provided a data that it is useful to assess the associations of MetS and its components and their alterations with the development of diabetes ${ }^{9}$. According to the UK Prospective Diabetes Study (UKPDS), metformin is an effective drug to control the blood glucose levels of obese type 2 diabetic patients ${ }^{10}$. It has been demonstrated that metformin is an effective drug for non-obese diabetic subjects in a short period of the observation, usually less than one year ${ }^{11-}$ ${ }^{13}$.Studies have shown that there is an association between metabolic syndrome and a high risk of coronary heart disease and premature mortality ${ }^{14}$. It is reported that metabolic syndrome like diabetes mellitus causes microvascular complications in type 2 diabetic patients ${ }^{15}$. Studies have indicated that $70-80 \%$ diabetic people are shown metabolic syndrome $^{16}$. Metformin is a drug has been approved by the Food and Drug Administration for the treatment of type 2 diabetic patients (T2DM). Metformin is as an effective drug that it differs in several respects. There are a number of factors which may make differences in anti-diabetic drug response in different population, such as age, sex, disease, drug and food interactions, co-morbidity, and genetic factors ${ }^{17}$. Metformin may decrease insulin resistance, weight loss and lactic acidosis which are the most serious side effect of metformin $^{18}$. Studies on oral antihyperglycemic drugs have been shown in some studies, but the knowledge is not enough for physicians to help and treat T2DM patients. Type 2 diabetic patients treated with $500 \mathrm{mg}$ and $1000 \mathrm{mg}$ per day metformin may be involved in the pathogenesis of the metabolic syndrome. The effects of different doses of this drug on the metabolic syndrome components are exactly unclear. The alterations of metabolic syndrome components may different in different ethnic groups. Thus, it may need to determine the effect of different doses of metformin on each component of MetS, which will be beneficial to early intervention and possible treatment of any related disease. The present study was designed to evaluate and compare the effect of different doses of metformin tablets monotherapy $(500 \mathrm{mg} /$ day and $1000 \mathrm{mg} /$ day) on metabolic syndrome components, with focus on women with type 2 diabetes mellitus in Gorgan, South East of Caspian Sea.

\section{MATERIALS AND METHODS}

From 250 type 2 diabetic patients, forty women patients diagnosed with type 2 diabetes mellitus (T2DM) who were treated by metformin tablets monotherapy were invited to participate and forty age matched healthy women were included in this study. The samples were collected and carried out in the private laboratory in Gorgan, South East of Caspian Sea, Iran. Our study condition was different with other studies. The type 2 diabetic patients were new case and they received metformin tablets for 12 months. They used these two doses of metformin from the beginning of our study. The patients were chosen with causal method and if each patient had our study condition then we selected them for our study. The study was conducted in accordance with the Declaration of Helsinki and Good Clinical Practice guidelines. The written informed consent was taken from all patients and healthy controls. The type 2 diabetic patients received $500 \mathrm{mg} /$ day (20 type 2 diabetic patients) and $1000 \mathrm{mg} /$ day (20 type 2 diabetic patients) metformin tablets monotherapy for 12 months. Patients in type 2 diabetic patients were followed up and they were on a carbohydrate restricted diet and no exercise. The doses of metformin that we used for type 2 diabetic patients $(500 \mathrm{mg} /$ day and $1000 \mathrm{mg} /$ day) for 12 months were different with other studies (especially the time condition, novelty of study). The healthy subjects were selected from among health care workers or from patient's relatives. There were no metabolic syndrome, no drug consumption 
and no some other diseases, etc. among healthy subjects. Patient's medical records collected and controlled with the help of patient information. Patients with type 1 diabetes, renal failure, hepatobilliary disease and hypothyroidism were excluded from the study.

The US National Cholesterol Education Program Adult treatment Panel III criteria were utilized to determine metabolic syndrome components ${ }^{19}$.These criteria consist of:

1. Waist circumference $\geq 102 \mathrm{~cm}$ (male), $\geq 88 \mathrm{~cm}$ (female).

2. Triglyceride $\geq 150 \mathrm{mg} / \mathrm{dl}$,

3. HDL-cholesterol $<40 \mathrm{mg} / \mathrm{dl}$ (male), < $50 \mathrm{mg} / \mathrm{dl}$ (female).

4. $\mathrm{BP} \geq 110 / \geq 85 \mathrm{mmHg}$.

5. Fasting blood glucose $\geq 110 \mathrm{mg} / \mathrm{dl}$.

Metabolic syndrome was determined according to ATPIII criteria ${ }^{19}$, if the subjects have three or more above mentioned criteria.

Body mass index (BMI) was measured using the metric measuring scale and formula

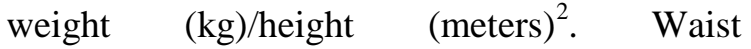
circumference was measured using a tape in centimeters. Blood pressure was measured with a digital blood pressure monitor (Omron 70 JCP; Omron Matsusaka, Mie-Ken, Japan). Blood samples were provided for all subjects after $12 \mathrm{hrs}$ fasting periods. All patients with type 2 diabetes mellitus had blood glucose higher than $126 \mathrm{mg} / \mathrm{dL}$. Serum fasting blood sugar, total cholesterol, low-density lipoprotein
(LDL)-cholesterol, high-density lipoprotein (HDL)-cholesterol, triglycerides and Hemoglobin A1C (HbA1C) measured by an automated enzymatic method. Insulin was determined by the ELISA commercial kit.

\section{Statistical analysis}

The SPSS Statistical Package was used to analyze the data (Version 16.0, Chicago, USA for Windows). The data were shown as mean \pm $\mathrm{SD}$ and percentage. The Chi-square test was used to determine the prevalence of metabolic syndrome in two groups of patients. Independent paired samples t-test was used to compare data between metformin received and control groups. The correlation between variables was determined by Pearson's correlation coefficient (r). P-Values lower than 0.05 were considered significant.

\section{RESULTS}

Table 1 shows the demographic and clinical characteristics of type 2 diabetic patients. A significant differences were found between the fasting blood sugar, triglycerides, high-density lipoprotein (HDL)-cholesterol, hemoglobin A1C (HbA1C) and insulin of the patients received $500 \mathrm{mg} /$ day and $1000 \mathrm{mg}$ /day metformin monotherapy $(p<0.001)$.

Table 1: Demographic and clinical characteristics of type 2 diabetic patients

\begin{tabular}{||l|c|c|c||}
\hline \multicolumn{1}{|c|}{ Parameters } & $\begin{array}{c}\text { Type 2 diabetic patients } \\
\text { received 500 mg } \\
\text { metformin }(\mathrm{n}=20)\end{array}$ & $\begin{array}{c}\text { Type 2 diabetic patients } \\
\text { received 1000 mg } \\
\text { metformin }(\mathrm{n}=20)\end{array}$ & P-value \\
\hline Mean age (years) & $43.28 \pm 28.45$ & $42.62 \pm 26.32$ & 0.780 \\
\hline Body Mass Index (BMI) & $24.29 \pm 12.08$ & $23.43 \pm 8.21$ & 0.564 \\
\hline waist circumference (cm) & $88.72 \pm 20.16$ & $88.87 \pm 22.12$ & 0.878 \\
\hline Systolic blood pressure (mmHg) & $135.46 \pm 15.23$ & $130.55 \pm 18.34$ & 0.234 \\
\hline Diastolic blood pressure (mm Hg) & $83.12 \pm 12.0$ & $80.14 \pm 8.70$ & 0.279 \\
\hline Fasting blood glucose (FBS) $(\mathrm{mg} / \mathrm{dL})$ & $99.76 \pm 17.65$ & $86.33 \pm 18.58$ & 0.001 \\
\hline Fasting serum triglyceride(mg/dL) & $135.89 \pm 36.78$ & $120.75 \pm 48.89$ & 0.001 \\
\hline Total cholesterol (mg/dL) & $211.62 \pm 67.32$ & $205.46 \pm 56.92$ & 0.923 \\
\hline $\begin{array}{l}\text { Fasting low density lipoprotein }(\mathrm{LDL}) \\
\text { cholesterol }(\mathrm{mg} / \mathrm{dL})\end{array}$ & $132.56 \pm 27.88$ & $128.36 \pm 32.36$ & 0.832 \\
\hline $\begin{array}{l}\text { Fasting high density lipoprotein }(\mathrm{HDL}) \\
\text { cholesterol }(\mathrm{mg} / \mathrm{dL})\end{array}$ & $58.85 \pm 12.17$ & $68.76 \pm 14.21$ & 0.001 \\
\hline HbA1c level $(\%)$ & $6.80 \pm 1.30$ & $5.0 \pm 1.50$ & 0.001 \\
\hline Insulin $(\mu \mathrm{IU} / \mathrm{mL})$ & $4.59 \pm 5.25$ & $8.78 \pm 4.36$ & 0.001 \\
\hline
\end{tabular}


Table 2: Demographic and clinical characteristics of type 2 diabetic patients received $500 \mathrm{mg}$ metformin and controls

\begin{tabular}{|l|c|c|c||}
\hline \multicolumn{1}{|c|}{ Parameters } & $\begin{array}{c}\text { Type 2 diabetic } \\
\text { patients received 500 } \\
\text { mg metformin }(\mathrm{n}=20)\end{array}$ & $\begin{array}{c}\text { Controls } \\
(\mathrm{n}=40)\end{array}$ & P-value \\
\hline Mean age (years) & $43.28 \pm 28.45$ & $42.67 \pm 18.42$ & 0.892 \\
\hline Body Mass Index (BMI) & $24.29 \pm 12.08$ & $24.77 \pm 8.92$ & 0.776 \\
\hline waist circumference (cm) & $88.72 \pm 20.16$ & $88.36 \pm 12.13$ & 0.975 \\
\hline Systolic blood pressure (mmHg) & $135.46 \pm 15.23$ & $133.22 \pm 15.21$ & 0.332 \\
\hline Diastolic blood pressure (mm Hg) & $83.12 \pm 12.0$ & $81.15 \pm 6.52$ & 0.674 \\
\hline Fasting blood glucose (FBS) (mg/dL) & $99.76 \pm 17.65$ & $109.66 \pm 12.25$ & 0.001 \\
\hline Fasting serum triglyceride(mg/dL) & $135.89 \pm 36.78$ & $148.22 \pm 25.14$ & 0.001 \\
\hline Total cholesterol (mg/dL) & $211.62 \pm 67.32$ & $210.13 \pm 48.16$ & 0.989 \\
\hline $\begin{array}{l}\text { Fasting low density lipoprotein (LDL) } \\
\text { cholesterol (mg/dL) }\end{array}$ & $132.56 \pm 27.88$ & $130.21 \pm 18.12$ & 0.967 \\
\hline $\begin{array}{l}\text { Fasting high density lipoprotein } \\
(\mathrm{HDL} \text { ) cholesterol (mg/dL) }\end{array}$ & $58.85 \pm 12.17$ & $50.33 \pm 8.19$ & 0.001 \\
\hline HbA1c level $(\%)$ & $6.80 \pm 1.30$ & $5.82 \pm 1.70$ & 0.001 \\
\hline Insulin $(\mu \mathrm{IU} / \mathrm{mL})$ & $4.59 \pm 5.25$ & $18.22 \pm 2.60$ & 0.001 \\
\hline
\end{tabular}

The metabolic syndrome components (except waist circumference and blood pressure) and $\mathrm{HbA} 1 \mathrm{c}$ levels in patients received $1000 \mathrm{mg} /$ day metformin was lower and HDLcholesterol and insulin levels were higher than those patients received $500 \mathrm{mg} /$ day metformin. No significant differences were found between other parameters treated with metformin in both groups $(p>0.5)$ (Table 1).

Table 2 shows demographic and clinical characteristics of type 2 diabetic patients received $500 \mathrm{mg}$ metformin and control groups. There were significant differences between the fasting blood sugar, triglycerides, high-density lipoprotein (HDL)-cholesterol, hemoglobin $\mathrm{A}_{1 \mathrm{C}}$ and insulin of the patients received $500 \mathrm{mg} /$ day and control groups $(p<0.001)$.The fasting blood sugar, triglycerides and insulin were lower and high-density lipoprotein (HDL)cholesterol and hemoglobin A1C were higher in patients received $500 \mathrm{mg} /$ day metformin than those control groups (Table 2). No significant differences were found between other parameters treated with metformin in both groups $(p>0.5)$ (Table 2).

Table 3 shows demographic and clinical characteristics of type 2 diabetic patients received $1000 \mathrm{mg}$ metformin and control groups. Significant differences were found between the fasting blood sugar, triglycerides, high-density lipoprotein (HDL)-cholesterol, hemoglobin A1C and insulin of the patients received $1000 \mathrm{mg} /$ day and control groups $(p<$ 0.001).The fasting blood sugar, triglycerides, hemoglobin $\mathrm{A} 1 \mathrm{C}$ and insulin were lower and high-density lipoprotein (HDL)-cholesterol was higher in patients received $1000 \mathrm{mg} /$ day metformin than control groups (Table 3). No significant differences were found between other parameters treated with metformin in both groups $(p>0.5)$ (Table 3$)$.

Correlations between variable pairs and different dose of metformin monotherapy are

shown in Table 4. In Both study groups a positive correlation was found between blood glucose and HbA1c and, blood glucose and triglyceride levels $(p<0.001)$, but the correlation in $1000 \mathrm{mg} /$ day metformin therapy was stronger than $500 \mathrm{mg} /$ day metformin therapy. There were a weak negative correlation between HbAlc and HDLCholesterol $(p<0.05)$ (Table 4).No significant differences were found between glucoseinsulin and insulin-HDL-cholesterol.

The prevalence of metabolic syndrome in $500 \mathrm{mg} /$ day and $1000 \mathrm{mg}$ /day received type 2 diabetic patients were $15 \%$ and $10 \%$, respectively (Not shown). 
Table 3: Demographic and clinical characteristics of type 2 diabetic patients received $1000 \mathrm{mg}$ metformin and controls

\begin{tabular}{|l|c|c|c||}
\hline \multicolumn{1}{|c|}{ Parameters } & $\begin{array}{c}\text { Type 2 diabetic patients } \\
\text { received 1000 mg } \\
\text { metformin }(\mathrm{n}=20)\end{array}$ & $\begin{array}{c}\text { Controls } \\
(\mathrm{n}=40)\end{array}$ & P-value \\
\hline Mean age (years) & $42.62 \pm 26.32$ & $42.67 \pm 18.42$ & 0.992 \\
\hline Body Mass Index (BMI) & $23.43 \pm 8.21$ & $24.77 \pm 8.92$ & 0.678 \\
\hline waist circumference (cm) & $88.87 \pm 22.12$ & $88.36 \pm 12.13$ & 0.978 \\
\hline $\begin{array}{l}\text { Systolic blood pressure } \\
\text { (mmHg) }\end{array}$ & $130.55 \pm 18.34$ & $133.22 \pm 15.21$ & 0.870 \\
\hline $\begin{array}{l}\text { Diastolic blood pressure } \\
\text { (mm Hg) }\end{array}$ & $80.14 \pm 8.70$ & $81.15 \pm 6.52$ & 0.773 \\
\hline $\begin{array}{l}\text { Fasting blood glucose } \\
\text { (FBS) (mg/dL) }\end{array}$ & $86.33 \pm 18.58$ & $109.66 \pm 12.25$ & 0.001 \\
\hline $\begin{array}{l}\text { Fasting serum } \\
\text { triglyceride(mg/dL) }\end{array}$ & $120.75 \pm 48.89$ & $148.22 \pm 25.14$ & 0.001 \\
\hline Total cholesterol (mg/dL) & $205.46 \pm 56.92$ & $210.13 \pm 48.16$ & 0.567 \\
\hline $\begin{array}{l}\text { Fasting low density } \\
\text { lipoprotein (LDL) } \\
\text { cholesterol (mg/dL) }\end{array}$ & $128.36 \pm 32.36$ & $130.21 \pm 18.12$ & 0.628 \\
\hline $\begin{array}{l}\text { Fasting high density } \\
\text { lipoprotein (HDL) } \\
\text { cholesterol (mg/dL) }\end{array}$ & $68.76 \pm 14.21$ & $50.33 \pm 8.19$ & 0.001 \\
\hline HbA1c level (\%) & $5.0 \pm 1.50$ & $5.82 \pm 1.70$ & 0.001 \\
\hline Insulin $(\mu \mathrm{IU} / \mathrm{mL})$ & $8.78 \pm 4.36$ & $18.22 \pm 2.60$ & 0.001 \\
\hline
\end{tabular}

Table 4: Pearson's correlation test applied to some metabolic syndrome components, HbA1c and insulin

\begin{tabular}{|l|c|c|c|c|}
\hline \multicolumn{1}{|c|}{ Variables } & \multicolumn{2}{c|}{$500 \mathrm{mg} /$ day metformin } & \multicolumn{2}{c|}{$1000 \mathrm{mg}$ /day metformin } \\
\hline & $\mathrm{r}$ & $\mathrm{P}$ & $\mathrm{R}$ & $\mathrm{p}$ \\
\hline Glucose-HbA1c & 0.15 & $<0.05$ & 0.29 & $<0.001$ \\
\hline Glucose- Triglycerides & 0.12 & $<0.05$ & 0.20 & $<0.001$ \\
\hline Glucose- Insulin & -0.07 & $>0.05$ & -0.06 & $>0.05$ \\
\hline HbA1c- HDL-Cholesterol & -0.62 & $<0.05$ & -0.71 & $<0.05$ \\
\hline Insulin- HDL-Cholesterol & 0.18 & $>0.05$ & 0.15 & $>0.05$ \\
\hline
\end{tabular}

\section{DISCUSSION}

This study showed that treatment of type 2 diabetic patients with $1000 \mathrm{mg} /$ day metformin monotherapy indicated significantly better effect on some metabolic syndrome components than those treated with $500 \mathrm{mg} / \mathrm{day}$ metformin. Patients with $1000 \mathrm{mg} /$ day metformin therapy revealed lower fasting blood sugar, triglyceride and $\mathrm{HbAlc}$ and higher HDL-cholesterol and insulin than in patients treated with lower doses of metformin. The $1000 \mathrm{mg} /$ day metformin treated patients produced a better effect than those treated with
$500 \mathrm{mg} /$ day metformin when compared with control groups. Our results show metformin monotherapy improved, especially fasting blood sugar, HDL-cholesterol, HbA1c and insulin levels. This may mean that 1000 $\mathrm{mg}$ /day metformin monotherapy has a more beneficial effect on these parameters and glycemic control, but not on blood pressure and all lipid profiles. Although the mechanism of metformin effect is not exactly clear. The most important variables for the evaluation of metabolic syndrome are triglyceride and HDLcholesterol. Some study showed that the metformin produces a more favorable effect on metabolic syndrome components. Many studies 
assessed the metformin effect on lipid profile and blood pressure ${ }^{20}$, while other findings showed an association of metformin with lipid profile in non-diabetic patients ${ }^{21}$. Some studies reported a decrease of triglyceride ${ }^{22-23}$, while other studies indicated a decrease of total cholesterol and triglycerides and an increase of HDL-cholesterol ${ }^{24-25}$. Metformin in our study decreases triglyceride and increase HDLcholesterol significantly in comparison with control groups. Some studies have indicated that metformin decreased blood pressure ${ }^{26-27}$ which is not in accordance with our study, while in agreement with our study; some others did not reveal any effect of metformin on blood pressure $^{28-30}$. Findings of Mourao Junior et al. ${ }^{29}$ showed that metformin received type 2 diabetic patients produced a significantly decreased WC, FBS, triglycerides and non-significant effects on blood pressure and on HDLcholesterol. Some of these findings are in accordance (Fasting blood sugar, triglyceride) with our results and some others are not in agreement with our findings (HDLcholesterol). Different studies demonstrate that metformin is effective in decreasing insulin resistance ${ }^{31}$. Several studies indicated that metformin has an effect on total cholesterol (TC), triglycerides (TG), and HDL-cholesterol (HDL-C) levels, and on blood pressure and body mass index $(\mathrm{BMI})^{20}$. The metformin did not significantly decrease blood pressure in our study agrees with other studies ${ }^{20 \& 32-34}$ while other studies reported the decrease of systolic blood pressure and diastolic blood pressure with metformin ${ }^{21 \& 35}$.The different results are indicated about the effect of metformin on lipid profile ${ }^{20}$. Some studies reported decrease in TC levels ${ }^{22-23}$, while others showed reduction of TC and TG with an increase of HDL-C ${ }^{24 \& 36}$. Some other studies revealed no alterations in lipid profile ${ }^{27 \& 37}$. Some of these findings are partially in accordance with our study. Studies of Garber et al. ${ }^{37}$ indicated that the drug's efficacy is dose-dependent. They reported that the minimal and maximal efficacious dose of metformin were $500 \mathrm{mg} /$ day and $2000 \mathrm{mg} /$ day, respectively. Some studies have shown that treatment with $500 \mathrm{mg} /$ day metformin in type 2 diabetic patients decreased fasting plasma glucose and $\mathrm{HbA}_{1 \mathrm{c}}$, but the patients treated with $2000 \mathrm{mg} /$ day showed the reduction of these parameters when compared with patients treated with $500 \mathrm{mg} /$ day metformin therapy ${ }^{37}$ 38. These findings are almost similar to our study. Several studies have shown the beneficial effect of metformin in non-obese diabetic patients ${ }^{11-13 \& 39-41}$. It is reported that the decrease of $\mathrm{HbAlc}$ by metformin was not significantly different between non-obese and obese Japanese type 2 diabetic patients for 12 months metformin treatment ${ }^{11}$. Studies showed a significant decrease in $\mathrm{Hb}_{\mathrm{Alc}}$ levels in patients with a normal BMI when compared with obese type 2 diabetic patients for 12 months metformin treatment ${ }^{42}$. It has also reported that metformin was more effective in type 2 diabetic patients with a lower $\mathrm{BMI}^{43}$. These findings were in accordance with our results in patients received $1000 \mathrm{mg} /$ day metformin monotherapy for 12 months. Different other studies indicated the metformin in non-obese and obese type 2 diabetic patients produce the similar glucose-lowering effect for study from 3 to 12 months $^{44}$. It is also reported that metformin was efficacious in non-obese type 2 diabetic patients ${ }^{45}$. The glucose-lowering effect of $500 \mathrm{mg} /$ day and $1000 \mathrm{mg} /$ day metformin monotherapy on glucose, triglyceride and $\mathrm{Hb}_{\mathrm{Alc}}$ and an increasing effect on HDL-cholesterol were seen in the present study and also the alteration of some metabolic syndrome components was achieved for one year treatment of non-obese type 2 diabetic patients with metformin. In the patients treated with $1000 \mathrm{mg} /$ day metformin, $\mathrm{Hb}_{\mathrm{Alc}}$ levels reached an ideal metabolic control (HbA1c: 5.0 $\pm 1.50 \%$ ). It seems that the rate of decrease of $\mathrm{Hb}_{\mathrm{Alc}}$ was faster in patients receiving high dose of metformin than low dose. Our results suggest that type 2 diabetic patients received $1000 \mathrm{mg} /$ day metformin therapy required no addition of other treatments after the initiation of metformin. The patient may benefit the use of metformin monotherapy in the treatment of type 2 diabetic patients. By using different doses of metformin, our correlation study indicated that $1000 \mathrm{mg}$ /day metformin therapy may show more effect on some metabolic syndrome components and $\mathrm{Hb}_{\mathrm{Alc}}$ levels than those treated with $500 \mathrm{mg} /$ day metformin in type diabetic patients. In our study, there was a strong positive association between fasting blood glucose and $\mathrm{HbA1c}$ and, fasting blood glucose and triglyceride in type 2 diabetic patients treated with $1000 \mathrm{mg} /$ day metformin 
compared with those treated with $500 \mathrm{mg} /$ day metformin, but there was a weak negative association between $\mathrm{HbAlc}$ and HDLcholesterol in the both groups. It is reported there are a positive correlation between fasting blood glucose and $\mathrm{Hb}_{\mathrm{Alc}}{ }^{20}$ which is similar to the results of our study.

Different studies have shown the possible molecular mechanism of metformin action which are started by the drug's activation of adenosine monophosphate (AMP)-activated protein kinase (AMPK). This enzyme causes suppression of glucose production via gluconeogenesis pathway and increased peripheral glucose uptake ${ }^{46-47}$. Metformin inhibit the hepatic gluconeogenesis pathway by phosphorylation and activation of AMPK through AMPK-dependent regulation of the orphan nuclear receptor small heterodimer partner, $\mathrm{SHP}^{48}$ and a protein-threonine kinase (LKB1), which shows the lowering effect of metformin $^{49}$. The mechanism of metformin action on AMPK activity is not exactly cleared. Metformin is a drug that it may exert a direct effect on pancreatic $\beta$-cells ${ }^{48 \& 50}$. The effect of metformin on $\beta$-cell function is still unclear. Different studies also have revealed that in human, metformin may had effect on pancreatic $\beta$-cell function and increased insulin release in response to glucose ${ }^{51}$. In vitro studies on rat islets cell indicated high levels of glucose and free fatty acids may have negative effect on metformin restored insulin secretion to $\beta$-cells ${ }^{52}$. The molecular mechanisms of metformin effect on $\beta$-cell function remain unknown.

The most important part of our study design was one year metformin monotherapy, matched age between patients and control groups, and normal BMI of women type 2 diabetic patients and control groups. Several studies have shown the effects of gender on the MS in different populations. In American white and blacks, Mexican American, Korea, Iran, India, Oman, women had higher prevalence of metabolic syndrome than men ${ }^{53}$. The study in Gorgan showed that females were more affected than males ${ }^{54}$. Different studies have indicated that prevalence of metabolic syndrome increases with age ${ }^{55}$. In our study, only women with closed average age were participated. Thus, the age and gender effects on metformin monotherapy, metabolic syndrome and their components were avoided in our study.

The results of this study had limitation. It is difficult to study the longtime treatment of metformin monotherapy of type 2 diabetic patients. The most referred type 2 diabetic patients did not have the conditions to participate in our study such as anti-diabetic combination drug therapy, duration of diabetes more than 1 year, gender (Only women type 2 diabetic patients) and age were limited our sample size.

\section{CONCLUSION}

In conclusion, our study showed the efficacy of the $1000 \mathrm{mg} /$ day metformin monotherapy on better control of blood sugar, $\mathrm{Hb}_{\mathrm{Alc}}$, triglyceride and HDL-cholesterol levels, but Metformin had no effect on waist circumference and blood pressure. Treatment with this dose of metformin may be more beneficial for type 2 diabetic patients than those other doses.

\section{Declarations:}

Ethics approval and consent to participate: The ethnic committee of Golestan University of Medical Sciences approval the study (With ethics number: IR.GOUMS.REC.1399.273).

Acknowledgements: The authors would like to thank the Research Deputy of Golestan University of Medical Sciences for approval the study. The corresponding author wishes to thank Mrs. Mona Mirzaali for her sincere help.

\section{REFERENCES}

1. S. Wild, G. Roglic, A. Green, R. Sicree and H. King, "Global prevalence of diabetes estimates for the year 2000 and projections for 2030", Diabetes Care, 27(5), 1047-1053 (2004).

2. WHO Global report on diabetes. http://www.who.int/diabetes/global-report /en/. Accessed May 9, 2016.

3. IDF diabetes atlas 2017 Atlas, $8^{\text {th }}$ edition. http://diabetesatlas.org/resources/ 2017atlas.html.

4. R. H. Eckel, S. M. Grundy and P. Z. Zimmet, "The metabolic syndrome", Lancet, 365 (9468), 1415-1428 (2005). 
5. F. Hadaegh, A. Ghasemi, M. Padyab, M. Tohidi and F. Azizi, "The metabolic syndrome and incident diabetes: assessment of alternative definitions of the metabolic syndrome in an Iranian urban population", Diabetes Res Clin Pract, 80 (2), 328-334 (2008).

6. S. Sacco, M. Comelli, V. Molina, P. L. Montrasio, E. Giani and F. Cavanna. "A simplified indication of metabolic syndrome to recognize subjects with a moderate risk to develop type 2 diabetes mellitus in a large Italian sample". Acta Diabetol, 51(1),35-41(2014).

7. N. Sattar, A. McConnachie, A. G. Shaper, G. J. Blauw, M. M. Buckley, A. J. de Craen, et al. "Can metabolic syndrome usefully predict cardiovascular disease and diabetes? Outcome data from two prospective studies". Lancet., 371(9628), 1927-1935, (2008).

8. R. Kahn, J. Buse, E. Ferrannini and M. Stern. "The metabolic syndrome: time for a critical appraisal. Joint statement from the American Diabetes Association and the European Association for the Study of diabetes"., Diabetologia, 48(9), 16841699, (2005).

9. W. C. Knowler, E. Barrett-Connor, S. E. Fowler, R. F. Hamman, J. M. Lachin, E. A. Walker, et al., "Diabetes Prevention Program Research Group. Reduction in the incidence of type 2 diabetes with lifestyle intervention or metformin"., $N$ Engl J Med, 346, 393-403 (2002).

10. UK Prospective Diabetes Study (UKPDS) Group: "Effect of intensive bloodglucose control with metformin on complications in overweight patients with type 2 diabetes (UKPDS 34)", Lancet, 352, 854-865 (1998).

11. K. Kaku, N. Tajima and K. Kawamori. "Melbin Observation Research (MORE) study of metformin therapy in patients with type 2 diabetes mellitus", J Japan Diab Soc, 49, 325-331 (2006).

12. S. S. Lund, L. Tarnow, C.D. Stehouwer, C. G. Schalkwijk, M. Frandsen, U. M. Smidtet, al: "Targeting hyperglycaemia with either metformin or repaglinide in non-obese patients with type 2 diabetes: results from a randomized crossover trial"., Diabetes Obes Metab, 9 (3), 394407 (2007).

13. S. S. Lund, L. Tarnow, M. Frandsen, B. Nielsen, B. Hansen, O. Pedersenet, et al. "Combining insulin with metformin or an insulin secretagogue in non-obese patients with type 2 diabetes: 12 month, randomised, double blind trial", $\boldsymbol{B M J}$, 339, b4324 (2009).

14. B. Isomaa, P. Almgren, T. Tuomi, B. Forsen, K. Lahti, M. Nissen, et al. "Cardiovascular morbidity and mortality associated with metabolic syndrome"., Diabetes Care, 24, 683-689 (2011).

15. Y. Shimajiri, K. Tsunoda, M. Furota, Y. Kadoya, S. Yamada, K. Nanjo, et al. "Prevalence of metabolic syndrome in Japanese type 2 diabetic patients and its significance for chronic vascular complications"., Diabetes Res Clin Pract, 79, 310-317 (2008).

16. G. Marchesini, G. Forlani, F. Cerrelli, R. Manini, S. Natale, L. Baraldi, et al. "WHO and ATP III proposals for the definition of the metabolic syndrome in patients with type 2 diabetes", Diabet Med, 21, 383-387 (2004).

17. J. Kirchheiner, I. Roots, M. Goldammer, B. Rosenkranz and J. Brockmoller. "Effect of genetic polymorphisms in cytochrome p450 (CYP) 2C9 and CYP2C8 on the pharmacokinetics of oral antidiabetic drugs: clinical relevance"., Clin. Pharmacokinet, 44, 1209-1225 (2005).

18. C. J. Bailey. "Biguanides and NIDDM"., Diabetes Care, 15, 755-772 (1992).

19. "Expert Panel on Detection and Evaluation of High Blood Cholesterol in Adults: Executive summary of the third report of the expert panel on detection, evaluation, and treatment of high blood cholesterol in adults (Adult Treatment Panel III)"., JAMA, 285, 2486-2497 (2001).

20. R. A. DeFronzo and A. M. Goodman. "Efficacy of metformin in patients with non-insulin-dependent diabetes mellitus. The Multicenter Metformin Study Group"., N Engl J Med, 333, 541-349 (1992). 
21. H. Ginsberg, J. Plutzky and B. E. Sobel. "A review of metabolic and cardiovascular effects of oral antidiabetic agents: beyond glucose level lowering", J Cardiovasc Risk, 6, 337-346 (1999).

22. P. J. Grant. "The effects of high and medium 1 dose metformin therapy on cardiovascular risk factors in patients with type II diabetes", Diabetes Care, 19, 6466 (1996).

23. H. YKI-Jarvinen, L. Ryysy, K. Nikkila, T. Tulokas, R. Vanamo and M. Heikkila. "Comparison of bedtime insulin regimens in patients with type 2 diabetes mellitus. A randomized, controlled trial", Ann Intern Med, 13, 389-396 (1999).

24. A. C. Robinson, J. Burke and S. Robinson, Johnston DG, Elkeles RS. "The effects of metformin on glycemic control and serum lipids in insulin treated NIDDM patients with suboptimal metabolic control", Diabetes Care, 21, 701-705 (1998).

25. D. Giugliano, A. Quatraro, G. Consoli, A. Minei, A. Ceriello, N. De Rosa, et al. "Metformin for obese, insulin treated diabetic patients: improvement in glycemic control and reduction of metabolic risk factors"., Euro J Clin Pharmacol, 44, 107-112 (1993).

26. K. Landin, L. Tengborn and U. Smith. "Treating insulin resistance in hypertension with metformin reduces both blood pressure and metabolic risk factors"., J Intern Medicine, 229, 181-187 (1991).

27. S. G. Rains, G. A. Wilson, W. Richmond and R. S. Elkeles. "The effects of glibenclamide and metformin on serum lipoproteins in type 2 diabetes", Diabet Med, 5, 653-658 (1988).

28. M. G. Wulffele, A. Kooy, D. de Zeeuw, C. D. Stehouwer and R. T. Gansevoort . "The effect of metformin on blood pressure, plasma cholesterol and triglycerides in type 2 diabetes mellitus: a systematic review", J Intern Med, 256, 1-14 (2004).

29. C. A. Mourao-Junior, J. R. Sa, O. M. Guedes and S. A. Dib. "Effects of metformin on the glycemic control, lipid profile, and arterial blood pressure of type 2 diabetic patients with metabolic syndrome already on insulin"., Braz $\boldsymbol{J}$ Med Biol Res, 39, 489-494 (2006).

30. J. P. Despres. "Potential contribution of metformin to the management of cardiovascular disease risk in patients with abdominal obesity, the metabolic syndrome and type 2 diabetes", Diabetes and Metabolism, 29, 6S53-6S61 (2003).

31. "American Diabetes Association. Diagnosis and classification of diabetes mellitus"., Diabetes Care., 33 (Suppl. 1):S62-S69 (2010).

32. J. C. Chan, B. Tomlinson, J. A. Critchley, C. S. Cockram and R. J. Walden. "Metabolic and hemodynamic effects of metformin and glibenclamide in normotensive NIDDM patients", Diabetes Care, 16, 1035-1038 (1993).

33. S. A. Isezuo, E. Ezunu. "Demographic and clinical correlates of metabolic syndrome in native African type 2 diabetic patients", J Natl Med Assoc, 97, 557-563 (2005).

34. G. N. Thomas, S. Y. Ho, E. D. Janus, K. S. Lam, A. J. Hedley and T. H. Lam. "The US National Cholesterol Education Programme Adult Treatment Panel III (NCEP ATP III) prevalence of the metabolic syndrome in a Chinese population", Diabetes Res Clin Pract, 67, 251-257 (2005).

35. E. Bonora, G. Targher, G. Formentini, F. Calcaterra, S. Lombardi, F. Marini, et al. "The metabolic syndrome is an independent predictor of cardiovascular disease in type 2 diabetic subjects"., Diabet Med, 21, 52-58 (2004).

36. L. Groop, E. Widen, A. Franssila-Kallunki, A. Ekstrand, C. Saloranta, C. Schalin, et al. "Different effects of insulin and oral antidiabetic agents on glucose and energy metabolism in type 2 (non-insulindependent) diabetes mellitus", Diabetologia, 32, 599-605 (1989).

37. A. J. Garber, T. G. Duncan, A. M. Goodman, D. J. Mills and J. L. Rohlf. "Efficacy of metformin in type II diabetes: results of a double-blind, placebocontrolled, dose-response trial", $\boldsymbol{A m} \boldsymbol{J}$ Med, 103, 491-497 (1997).

38. K. Hosokawa, S. Meguro, O. Funae, C. Murata, K. Katou, A. Mokubot, et al. 
"Clinical effects of metformin with nonobese type 2 diabetes", J Japan Diab Soc, 52, 1-6 (2009).

39. B. F. Clarke and I. W. Campbell. "Comparison of metformin and chlorpropamide in non-obese, maturityonset diabetics uncontrolled by diet", $\boldsymbol{B r}$ Med J, 2(6102), 1576-1578 (1977).

40. K. Yajima, A. Shimada, H. Hirose, A. Kasuga and T. Saruta. "Low dose" metformin improves hyperglycemia better than acarbose in type 2 diabetics", Rev Diabet Stud, 1, 89-94 (2004).

41. L. A. Donnelly, A. S. Doney, A. T. Hattersley, A. D. Morris and E. R. Pearson. "The effect of obesity on glycaemic response to metformin or sulphonylureas in Type 2 diabetes", Diabet Med, 23, 128-133 (2006).

42. C. R. Ong, L. M. Molyneaux, M. I. Constantino, S. M. Twigg and D.K. Yue. "Long-term efficacy of metformin therapy in nonobese individuals with type 2 diabetes"., Diabetes Care., 29, 2361-2364 (2006).

43. P. Marchetti, D. W. Scharp, R. Giannarelli, L. Benzi, P. Cicchetti, A. M. Ciccarone, et al. "Metformin potentiates glucosestimulated insulin secretion", Diabet Care, 19, 781-782 (1996).

44. P. Marchetti, R. Lupi, S. Del Guerra, M. Bugliani, V. D'Aleo, M. Occhipinti, et al. "Goals of treatment for type 2 diabetes: beta-cell preservation for glycemic control", Diabet Care, 32, 178-183 (2009).

45. R. Saeedi, H. L. Parsons, R. B. Wambolt, K. Paulson, V. Sharma, J. R. Dyck, et al. "Metabolic actions of metformin in the heart can occur by AMPK-independent mechanisms", Am J Physiol, 294, 24972506 (2008).

46. W. Abbud, S. Habinowski, J. Z. Zhang, J. Kendrew, F. S. Elkairi, B. E. Kemp, et al. "Stimulation of AMP-activated protein kinase (AMPK) is associated with enhancement of Glut1-mediated glucose transport", Arch Biochem Biophys, 380, 347-352 (2000).

47. G. Zhou, R. Myers, Y. Li, Y. Chen, X. Shen, J. Fenyk-Melody, et al., "Role of
AMP-activated protein kinase in mechanism of metformin action", $\boldsymbol{J}$ Clin Invest, 108, 1167-1174 (2001).

48. Y. D. Kim, K. G. Park, Y. S. Lee, Y. Y. Park, D. K. Kim, B. Nedumaran, et al. "Metformin inhibits hepatic gluconeogenesis through AMP-activated protein kinase-dependent regulation of the orphan nuclear receptor SHP", Diabetes, 57, 306-314 (2008).

49. R. J. Shaw, K. A. Lamia, D. Vasquez, S. H. Koo, N. Bardeesy, R. A. Depinho, et al. "The kinase LKB1 mediates glucose homeostasis in liver and therapeutic effects of metformin", Science, 310, 16421646 (2005).

50. G. Patane, S. Piro, A. M. Rabuazzo, M. Anello, R. Vigneri, F. Purrello. "Metformin restores insulin secretion altered by chronic exposure to free fatty acids or high glucose: a direct metformin effect on pancreatic beta-cells", Diabetes, 49, 735-740 (2000).

51. A. Mohsin, J. Zafar, S. M. Imran, K. Zaheer, B. Khizar, R. A. Qazi. "Frequency of the metabolic syndrome in adult type 2 diabetics prescribing to institute of medical sciences"., J Pak Med Asso, 57, 235-239 (2007).

52. C. Lorenzo, M. Okoloise, K. Williams, Stern MP, Haffner SM. San Antonio Heart Study. "The metabolic syndrome as predictor of type 2 diabetes: the San Antonio heart study", Diabetes Care, 26 (11), 3153-3159 (2003).

53. P. W. Wilson, R. B. D'Agostino, H. Parise, L. Sullivan and J. B. Meigs. "Metabolic syndrome as a precursor of cardiovascular disease and type 2 diabetes mellitus"., Circulation, 112 (20), 3066-3072 (2005).

54. A. Marjani, A. Shirafkan. "The metabolic syndrome in type 2 diabetic patients in Gorgan: According to NCEP ATPIII and IDF definitions", Diabetes Metab Syndr, 5(4), 207-210 (2011).

55. A. Marjani and N. Shahini. "Age related metabolic syndrome among Fars ethnic women in Gorgan", Iran J Pharm Biomed Sci, 30 (30), 929-935 (2013). 


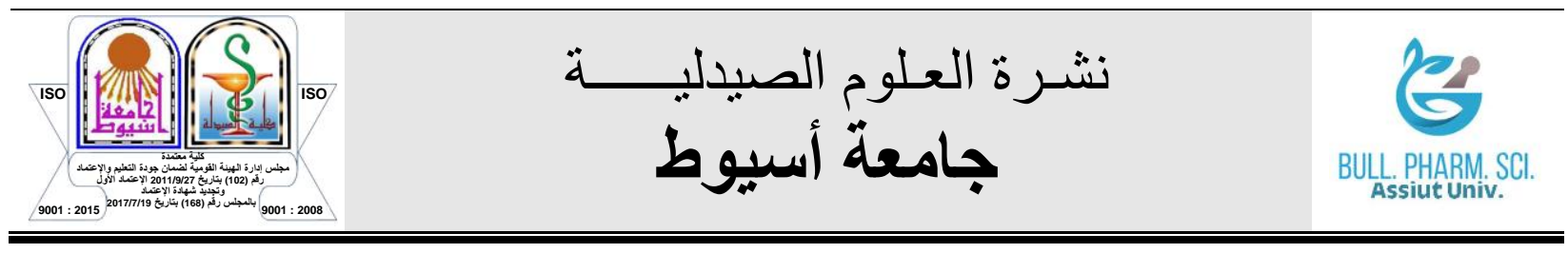

تأثير الجرعات المختلفة من أقراص الميتفورمين على مكونات متلازمة التمثيل

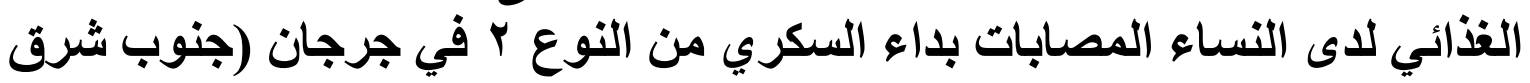
بحر قزمين)

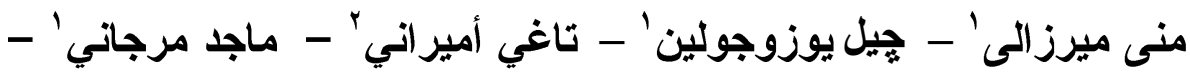

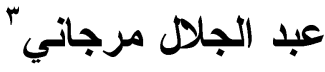

اكلية الصيدلة ، جامعة شرق البحر الأبيض المتوسط ، 997 ، 9 ، فاماغوستا ، شمال قبرص عبر مرسين • 1 ، تركيا 'مركز أبحاث جولستان لأمـراض الجهاز الهضـمي والكبـد، جامعـة جولستان للعلـوم الطبيـة ، جرجـان ، مقاطعة جولستان ، إيران مركز أبحاث اضطرابات التمثيل الغذائي ، قسم الكيمياء الحيوية والفيزياء الحيويـة ، جامعـة جولستان للعلـوم الطبية ، جرجان ، مقاطعة جولستان ، إيران

أظهرت بعض الدراسات التي أجريت على الأدوية المضادة لفرط سكر الدم عن طريق الفم أنها

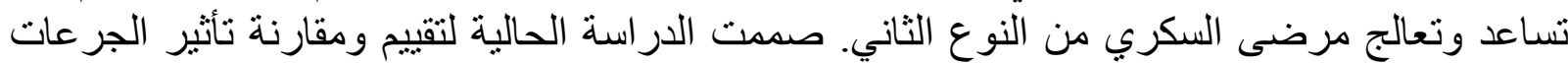

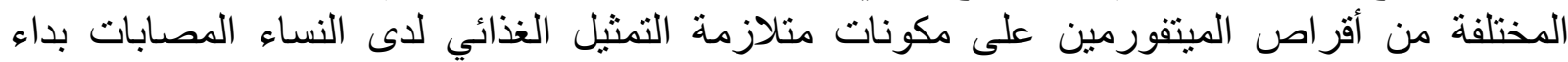

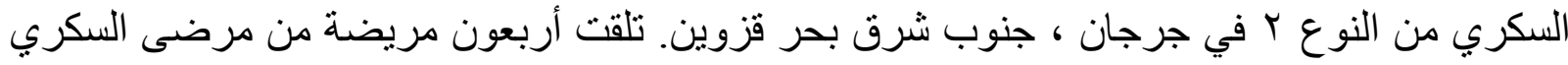

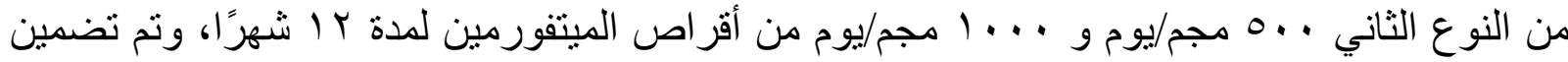

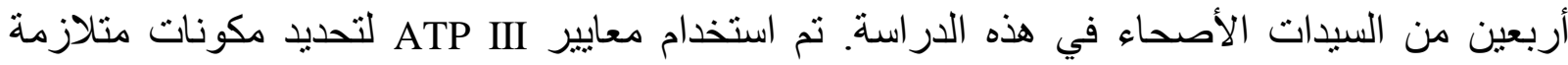

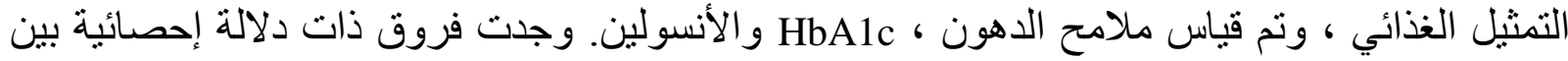

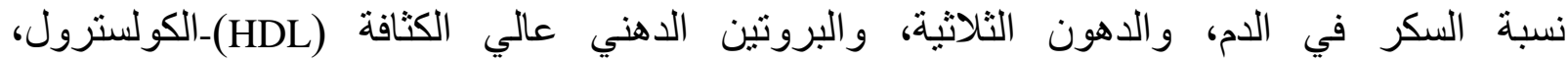

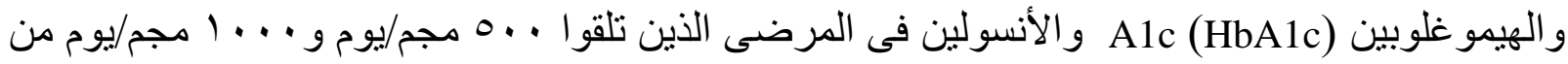

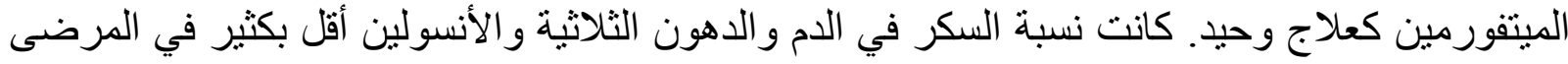

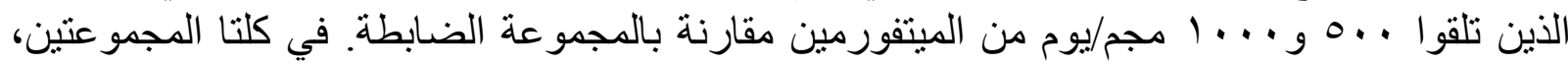

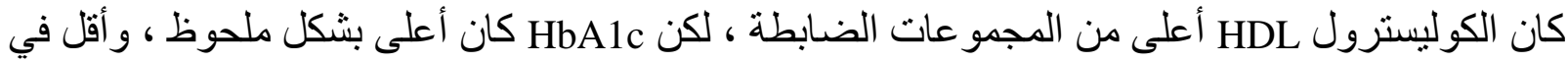

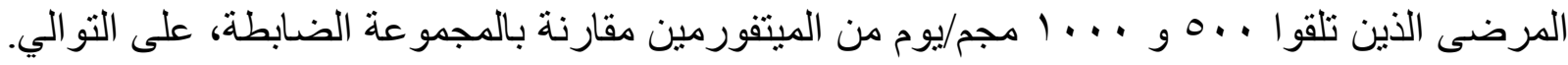
في كلتا مجموعتي الدراسة، تم العثور على ارتباط إيجابي معنوي بين الجلوكوز في الدم و و

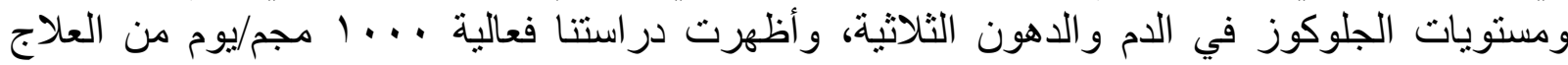
بالميتفورمين الأحادي في التحكم بشكل أفضل في نسبة السكر في الدم، و و

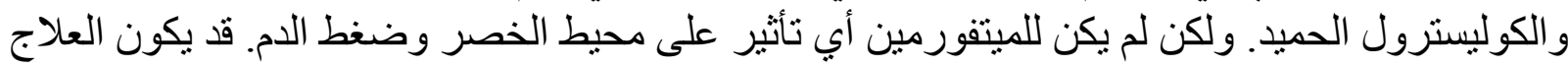

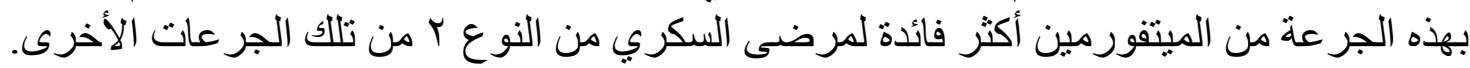

